\section{Yesterday's new s}

\section{Controlling Our Destinies: Historical, Philosophical, Ethical, and Theological Perspectives on the Human Genome Project Edited by Phillip R. Sloan \\ University of Notre Dame Press, \$20.00, ISBN 0-268-00818-3, 2000}

\section{Review ed by Glenn McGee}

Associate Director, University of Pennsylvania Center for Bioethics, Philadelphia, Pennsylvania, USA

There are so many anthologies that purport to examine the "ethical, legal and social implications" raised by the Human Genome Initiative; the feeling is of the hundredth visit to a nouveau Manhattan restaurant: the menu is different, the name is different, the food looks different, but the polenta is still cornmeal. Unless you have ignored bioethics during the past ten years, the present volume is indeed a familiar meal. The University of Notre Dame Press has brought to the table essays from a six-year-old conference on genetics, under the editorship of Phillip Sloan. Controlling Our Destinies is a collection of 16 essays devoted to the roots and foundations of genetic research. The book is handsomely bound in paperback with a thorough index, and its four sections assemble leaders amply equipped to discuss the origins of genetic research, eugenics and reductionism. Although the book purports to cover problems in theological as well as philosophical perspectives, notably missing is any religious ecumenism.

The essays presented in Controlling Our Destinies cover a disparate range of methods and topics. The familiar problems of the 1990s debate about genetics are all addressed: how shall reductionism have an impact on human institutions and theories of human nature? What sorts of inequalities might be perpetuated or furthered by the potential for genetic enhancement? How does the historical phenomenon of eugenics relate to contemporary reproductive choice, and what if anything is morally wrong with eugenics? One can imagine a spirited debate about these fundamental questions at the rural Indiana campus of Notre Dame which, like this volume, is somewhat removed from the practical exigencies of clinical genetics.

Worthy of note are Phillip Kitcher's essay on the economic and philosophical problems of justice in allocation of genetic goods, an essay that finds itself much more fully elaborated in his later book on the subject, and Evelyn Fox Keller's revisiting of her analysis of the problem of symbolization of genetic information. Kenneth Schafner offers perhaps the most rigorous essay in the volume, a discussion of determinism in the genetic analysis of complex and simple organisms. Novel in this collec-

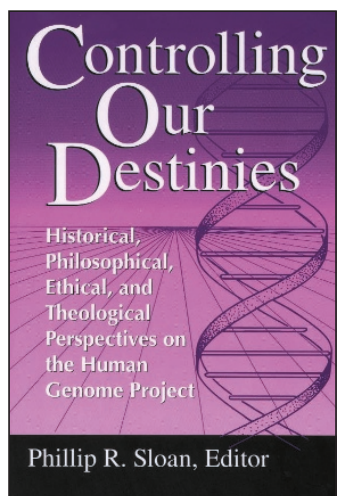

and bioethics, or so far from the present concerns of policymakers and scientists, as to render this a historical document; this is the record of an interesting conference, one among many on genetics to be held in the mid 1990s. I am sure this is not what the highly skilled authors of these papers intended when they penned their comments; it is clear, to the contrary, that many hoped the present volume would open new vistas of debate.

But this is the dilemma of books about genetics: by the time they come into print, often the entire scope of the dilemma, including the historical problems of interest, has shifted. Tectonic shifts in genetics and genomics have made the present volume useless as a teaching collection, indeed it is interesting only to those who missed other iterations of these arguments penned in other forums by the same authors. Even the best libraries could avoid this volume without missing many of the arguments within. More depressing, the most important issues such a collection could address (particularly given the auspicious cast of authors), the ownership of genetic information, the meaning of 'therapeutic' gene therapy, the ways in which protein twisting tion are Kevin Fitzgerald's discussion of philosophical anthropology and (what was then termed) the Genome Project, and John Beatty's discussion of the role of national security actually played in the developing genome project. Taken as a whole, there is nothing unpalatable about the collection of richly annotated essays in the volume.

One can only wonder, however, why the University of Notre Dame Press waited so long to release this volume of essays. Many of the problems discussed here are either so thoroughly covered in the peer-reviewed literature of genetics affects reductionist analysis, the evolution of a biotechnology marketplace, and the relationship between genetics and post-1997 reproductive technologies, are missing.

Despite careful editing, thoughtful introduction, a variety of good and clear papers, and an outstanding index, the medium has undermined the message of this trenchant volume. Nonetheless, the editor and authors are to be commended for their hard work and for a very thoughtful and exhaustive review of the state of theory about genetics in 1995. 